\title{
PENGARUH EFEKTIFITAS DAN EFISIENSI KERJA TERHADAP KINERJA PEGAWAI PADA KANTOR KECAMATAN BANGGAE TIMUR
}

\author{
Shofiana Syam \\ Politeknik Informatika Nasional \\ Email: shofianasyam@yahoo.co.id
}

\begin{abstract}
To get a maximum result or an effective and efficient team work certainly requires good communication between individuals in an organization. Effectiveness Is a measure of an organization in achieving better work processes in completing tasks. Work efficiency is the best comparison between a job done and the results achieved by the work in accordance with those targeted both in terms of quality and results. The research conducted at the East Banggae Sub-district office uses multiple linear regression analysis methods. The study was conducted for 3 months, from January to March 2020. The results showed that: 1) there was a significant effect of effectiveness on the Performance of Employees at the East Banggae District Office, partially, 2) There was a significant effect of Work Efficiency on Employee Performance at the District Office East Banggae, partially, 3) there is a significant influence between effectiveness and work efficiency on employee performance at the East Banggae sub-district office simultaneously and the results show that the value of these two variables influences the optimal achievement of Employee Performance.
\end{abstract}

\begin{abstract}
Abstrak
Untuk mendapatkan sebuah hasil yang maksimal atau tim kerja yang efektif dan efisien tentunya di butuhkan komunikasi yang baik antar individu di dalam sebuah organisasi. Efektifitas Merupakan ukuran suatu organisasi dalam mencapai proses kerja yang lebih baik dalam menyelesaikan tugas. Efisiensi kerja adalah perandingan terbaik antara suatu pekerjaan yang di lakukan dengan hasil yang dicapai oleh pekerjaan tersebut sesuai dengan yang ditargetkan baik dalam hal mutu maupun hasilnya. Penelitian yang dilakukan di kantor Kecamatan Banggae Timur ini menggunakan metode analisa regresi linier berganda. Penelitian dilakukan selama 3 bulan yaitu mulai Januari sampai Maret 2020. Hasil penelitian menunjukkan bahwa: 1) terdapat pengaruh efektifitas yang signifikan terhadap Kinerja Pegawai Pada Kantor Kecamatan Banggae Timur, secara parsial, 2) ada Pengaruh Efisiensi Kerja yang signifikan terhadap Kinerja Pegawai Pada Kantor Kecamatan Banggae Timur, secara parsial, 3) ada pengaruh yang signifikan antara efektifitas dan efisiensi kerja terhadap kinerja pegawai pada kantor kecamatan Banggae Timur secara simultan dan dari hasil tersebut menunjukkan bahwa nilai kedua variabel tersebut berpengaruh terhadap pencapaian Kinerja Pegawai yang optimal.
\end{abstract}




\section{PENDAHULUAN}

Penerapan Pelayanan sangat di pentingkan artinya dalam rangka peningkatan kinerja, penyediaan dan pelayanan kepada masyarakat secara nyata, efisiensi dan bertanggung jawab dengan mengacu pada arah dan kebijakan suatu kantor. Hal tersebut dapat di lakukan apabila sumber daya manusia menunjang dan berkualitas, artinya bahwa pembinaan dan pengembangan sumber daya manusia jauh lebih penting untuk segera di tangani. dengan berbagai langkah dan strategi yang tepat.

Pengembangan sumber daya manusia pada dasarnya adalah peningkatan kerja yang mencerminkan kemampuan anggota organisasi dalam bekerja, artinya kinerja masing-masing Suatu organisasi tentunya memiliki suatu tujuan yang sudah dikehendaki, pada dasarnya setiap organisasi memiliki keinginan untuk mendapatkan hasil kinerja yang lebih efektif dan efisien. Organisasi sering dikatakan sebagai tempat dari upaya pencapaian kerjasama tim dalam meraih tujuan.

Dalam mencapai tujuan organisasi tersebut, permasalahan yang dihadapi bukan hanya alat-alat kerja, lingkungan kerja dan sumber daya manusia saja, tetapi menyangkut kerjasama antar pegawai dalam suatau organisasi. Kerjasama tim merupakan salah satu unsur fudemental dalam TQM (Total Quality Manajemen). Tim merupakan sekelompok orang yang memiliki tujuan bersama. Faktor yang mendasar perlu dibentuknya tim tentunya adalah sebagai berikut; pemikiran 2 orang atau lebih cenderung lebih baik; anggota tim dapat saling mengenal dan percaya; kerjasama tim dapat menyebabkan komunikasi terbina dengan baik; dan juga konsep sinergi (Nasution, 2010:220). Menurut Daft (2019:12) definisi resmi untuk organisasi (organization) adalah entitas sosial yang diarahkan dengan tujuan dan dengan penuh pertimbangan. Entitas sosial berarti terdiri dari dua orang atau lebih.

Hal ini memberikan pengertian di dalam organisasi terdiri beberapa orang yang bekerjasama untuk meraih tujuan yang sama. Dengan mempertimbangkan dua hal tersebut kinerja sebuah oraganisasi tidak akan lepas dari sebuah kerjasama tim. Dibutuhkan peran aktif dari pegawai dan tim yang solid agar dapat terwujudnya tujuan yang sudah di kehendaki. Menurut Tenner dan Dintoro (2009: dalam Poernomo, 2019:104) kerjasama tim adalah sekelompok orang yang bekerja bersama untuk mencapai tujuan yang sama dan tujuan tersebut akan mudah di peroleh dengan melakukan kerjasama tim daripada dilakukan sendiri.

Kerjasama berbeda dengan bekerja bersama-sama. Kerjasama lebih merujuk pada upaya menyelesaikan tugas dalam rangka mencapai tujuan antar orangperorangan atau antar satuan kerja dimana masing-masing memiliki ketugasan yang dilakukan secara sinergis, sedangkan bekerja bersamasama lebih merujuk bekerja antar orang perorangan atau antar satuan kerja yang dilakukan dalam waktu yang sama yang belum tentu disertai pengerjaan tugas secara sinergis (Soedarmanto, 2009:145).

Untuk mendapatkan sebuah hasil yang maksimal atau tim kerja yang efektif dan efisien tentunya di butuhkan komunikasi yang baik antar individu di dalam sebuah organisasi. Sedang menurut Nelson \& Tonks (2007: dalam Tarigan, dkk; 2012:25) Komunikasi yang 
dibangun oleh setiap individu lambat laun akan membentuk suatu group kerja yang memiliki kesamaan pada organisasi perusahaan. Kumpulan dua atau lebih individu yang saling berinteraksi tanpa adanya keharusan memiliki keahlian (skills) atau tanpa adanya komitmen antara anggota kelompok namun memiliki kesamaan tujuan disebut dengan group.

Teamwork mewakili suatu kesatuan nilai yang menganjurkan anggotanya untuk saling mendengarkan, memberikan respon yang membangun, mendukung dan mengapresiasi keinginan dan kesusksesan anggota team (Huetal.,2009). Menurut Gie (2010:173) efisiensi kerja adalah perbandingan terbaik antara suatu kerja dengan hasil yang dicapai oleh kerja itu. Dengan tak mengabaikan faktor-faktor lainnya yang ikut mempengaruhi sesuatu kerja, maka perbandingan terbaik antara usaha dengan hasilnya dalam kerja itu terutama ditentukan caranya melakukan aktivitas yang bersangkutan. Jadi, efisiensi kerja pada umumnya merupakan perwujudan dari cara-cara kerja yang memungkinkan tercapainya perbandingan terbaik antara usaha dan hasil, yaitu cara-cara kerja yang efisien. Kerjasama tim sangat diperlukan guna meningkatkan efisiensi kerja baik itu di Kantor, swasta maupun pemerintahan. Jika perusahaan tidak memiliki kerjasama yang kuat antara devisi satu dengan devisi lainnya, maka hasil dari kerjanya tidak efisien atau tepat waktu (Rolanna, 2008:2).

Untuk mendapatkan hasil yang lebih maksimal diperlukan keaktifan para anggota untuk saling mencari solusi dari masalah yang ada. Artinya pada Sub Bagian Umum dan Kepegawaian kerjasama tim sudah dilakukan dengan baik namun hasil kinerja belum baik. Disisi lain menurut Edmondson (2007: dalam Tarigan, dkk; 2012: 28) suatu tim dapat mencapai suatu kinerja tertinggi bila anggota tim secara aktif melakukan diskusi, banyak bertanya dan banyak mencari solusi melalui suatu eksperimen. Berdasarkan latar belakang di atas, maka penulis tertarik untuk mengangkat tema penelitian dengan judul "Pengaruh Efektifitas dan Efisiensi kerja Terhadap Kinerja Pegawai Pada Kantor Kecamatan Banggae Timur"

\section{TINJAUAN PUSTAKA}

\subsection{Efektifitas}

\section{a. Pengertian Efektifitas}

Efektifitas Merupakan ukuran suatu organisasi dalam mencapai proses kerja yang lebih baik dalam menyelesaikan tugas. Berbagai teratur konsep yang membahas efektifitas kinerja menunjukkan hasil yang dicapai dalam arti bahwa efektitifitas kerja adalah suatu kegiatan yang diukur besar kecilnya penyesuain antara tujuan dan harapan yang ingin dicapai dalam kerja dengan hasil yang baik. jelasnya jika sasaran atau tujuan telah tercapai sesuai sumber dengan yang telah direncanakan sebelumnya dapat disebut efektif.

Pengertian efektifitas Dalam dunia ekonomi khususnya dalam ilmu manajemen,kata efektifitas sering sobat dengar,di bawah ini pengertian atau definisi efektifitas menurut beberapa ahli ekonomi yaitu sebagai berikut: Menurut Prasetyo Budi Saksono,(2009:12) bahwa efektifitas adalah seberapa besar tingkat kelekatan output (keluaran) yang dicapai dengan output yang diharapkan dari jumlah input (masukan) dalam suatu perusahaan atau seseorang. Menurut Hidayat, (2011:18) 
bahwa efektifitas adalah suatu ukuran perusahaan yang menyatakan seberapa target yakni kuantitas, kualitas dan waktu telah tercapai secara jauh, dimana makin besar persentase target yang dicapai maka akan makin tinggi efektifitasnya. Menurut Schemerhon Johnr.Jr.,(2018:23) bahwa efektifitas adalah pencapaian target keluaran (output) yang akan di ukur dengan cara membandingkan output anggaran atau OA (seharusnya) dengan output realisasi atau OS (sesungguhnya) jika $O A>0 S$ maka akan disebut dengan efektif.

Berdasarkan efektifitas menurut beberapa ahli ekonomi di atas dapat disimpulkan bahwa pada dasarnya pengertian efektifitas adalah suatu keadaan yang menunjukkan seberapa jauh suatu target yang telah dicapai oleh manajemen seperti kualitas, kuantitas dan waktu, dimana target tersebut sudah ditentukan terlebih dahulu. semakin banyak suatau target yang dapat di capai maka akan semakin efektif pula kegiatan tersebut. Kata efektifitas juga dapat di artikan sebagai usaha tertentu atau suatu tingkat keberhasilan yang dapat dicapai oleh seseorang atau suatu perusahaan .

\section{b. Perencanaan Kriteria Efektifitas}

Suatu kegiatan atau aktifitas dapat dikatakan efektif bila memenuhi beberapa kriteria tertentu efektifitas sangat berhubungan dengan terlaksananya semua tugas pokok. Tercapainya tujuan ketepatan waktu serta adanya usaha atau partisipasi aktif dari pelaksana tugas tersebut. secara umum beberapa tolak ukur atau kriteria efektifitas adalah sebagai berikut:

1) Efektifitas keseluruhan, yaitu sejauh mana seseorang atau organisasi melaksanakan seluruh tugas pokoknya.
2) Produktifitas, yaitu kuantitas produk atau jasa pokok yang dihasilkan seseorang, kelompok atau organisasi.

3) Efisiensi kerja yaitu ukuran keberhasilan suatu kegiatan yang dinilai berdasarkan besarnya sumber daya yang digunakan untuk mencapai hasil yang di inginkan.

4) Laba yaitu keuntungan atas penanaman modal yang di pakai untuk menjalankan suatu kegiatan.

5) Pertumbuhan, yaitu suatu perbandingan antara keadaan organisasi sekarang dengan keadaan masa sebelumnya (tenaga kerja, fisilitas, harga penjualan dan lainnya).

\section{c. Faktor-Faktor}

Yang

\section{Mempengaruhi Efektifitas}

1) Waktu

Ketetapan waktu dalam menyelasaikan suatu pekerjaan merupakan faktor utama. semakin lama tugas dibebankan itu dikerjakan, maka semakin banyhak tugas lain yang menyusul dan hal ini memperkecil tingkat efektifitas kerja karena memakan waktu yang tidak sedikit.

2) Tugas

Tugas bawahan harus di beri tahukan maksud dan pentingnya tugastugas yang dilegalisirkan kepada mereka.

3) Produktifitas

Seorang pegawai mempunyai produktifitas yang tinggi dalam bekerja tentunya akan dapat menghasilkan efektifitas kerja yang baik demikian pula sebaliknya.

4) Motivasi

Pemimipin dapat mendorong bawahan melalui perhatian pada kebutuhan dan tujuan mereka yang sensitif semakin termotifasi pegawai untuk bekerja secara positif semakin baik pula kinerja yang dihasilkan. 
5) Evaluasi Kerja

Pimpinan memberikan dorongan, bantuan dan informasi kepada bawahan sebaliknya bawahan harus melaksanakan tugas dengan baik atau tidak.

6) Pengawasan

Dengan adanya pengawasan maka kinerja pegawai dapat terus terpantau dan hal ini dapat memperkecil resiko kesalahan dalam pelaksanaan tugas.

7) Lingkungan Kerja

Lingkungan tempat bekerja adalah menyangkut tata ruang cahaya dan pengaruh suara yang mempengaruhi konsentrasi seseorang pegawai sewaktu bekerja.

8) Perlengkapan dan Fasilitas

Perlengkapan fasilitas adalah suatu sarana dan peralatan yang disediakan oleh pimpinan dalam bekerja. semakin baik saran yang disediakan oleh perusahaan akan mempengaruhi semakin baik kerja seseorang dalam mencapai tujuan atau hasil yang diharapkan.

Berdasarkan uraian diatas dapat diketahui bahwa faktor waktu tugas, produktifitas, motivasi, evaluasi kerja, pengawasasn serta lingkungan kerja dan kelengkapan fasilitas sangat mempengaruhi peningkatan efektifitas dari seorang pegawai. Apabila faktor tersebut tidak ada maka organisasi sulit meningkatkan efektifitas kerja pegawainya.

Kemiliteran, dan sebagainya (ketaatan/kepatuhan terhadap tata tertib di sekolah). Sedangkan pola asuh berarti bentuk atau sistem dalam menjaga, merawat dan mendidik. Jika ditinjau dari terminologi, pola asuh anak adalah suatu pola atau sistem yang diterapkan dalam menjaga, merawat dan mendidik seorang anak yang bersifat relatif konsisten dari waktu ke waktu. Pola perilaku ini dapat dirasakan oleh anak dari segi negatif atau positif.

\section{d. Manfaat Efektifitas}

Seperti telah di ketahui bahwa efektifitas adalah masalah pencapaian tujuan. maka hal ini tentunya bermanfaat bagi organisasi pencapain tujuan menentukan keberhasilan bagi organisasi dalam operasinya sekaligus didalamnya manyangkut tujuan organisasi sendiri, pegawai dan pihak dari luar organisasi selanjutnya Gie (2012:27) menyatakan bahwa efektifitas memiliki empat sikap utama yaitu.

1) Berorientasi pada kondisi ekonomi secara menyeluruh dan bersifat umum untuk daerah tertentu Menjamin terhadap perkembangan industri dan pertumbuhannya, sehingga dapat melahirkan suatu hasil tertentu dalam pernyataan.

2) Menentukan tindakan tertentu bagi pemerintah dan menjalankan program dan mengikut sertakan tindakan tertentu dan menjalankan program melihat dari manfaat efektifitas kerja.

\subsection{Efisiensi Kerja}

\section{a. Pengertian Efisiensi Kerja}

Secara umum pengertian efisiensi kerja adalah perandingan terbaik antara suatu pekerjaan yang di lakukan dengan hasil yang dicapai oleh pekerjaan tersebut sesuai dengan yang ditargetkan baik dalam hal mutu maupun hasilnya. Agar memahami apa arti efisiensi kerja kita dapat merujuk pada para ahli berikut ini adalah pengertian efisiensi menurut Susilo,(2011:28) adalah suatu kondisi atau keadaan, dimana penyelesaian suatu pekerjaan dilaksanakan dengan benar dan dengan penuh kemampuan yang di miliki. 
Menurut Soekartawi,(2010:220) pengertian efisiensi kerja adalah upaya penggunaan input yang sekecil-kecilnya untuk pendapatkan produksi yang sebesar-besarnya. Perbandingan ini dilihat dari :

1) Segi waktu, suatu perkerjaan disebut lebih efisien bila hasil kerja berdasarkan patokan ukuran yang di inginkan untuk memperoleh sesuatu yang baik dan maksimal.

2) Segi kinerja, yaitu hasil kerja secara kualitas dan kuantitas yang dicapai oleh seorang karyawan dalam melaksanakan tugasnya sesuai dengan tanggung jawab yang diberikan.

Berdasarkan uraian diatas bahwa perandingan terbaik antara usaha dan hasilnya dalam setiap pekerjaan terutama ditentukan oleh bagaimana pekerjaan itu dilakukan. Jika efisiensi kerja pada umumnya merupakan hasil dari cara-cara kerja yang sesuai dengan prosedur kerja. Cara kerja yang efisien adalah cara yang tanpan sedikitpun mengurangi hasil yang hendak dicapai seperti : cara termudah, tercepat, termurah, teringan, dan terpendek

\section{b. Tujuan dan manfaat efisiensi kerja}

Efisiensi kerja sering dilakukan pada berbagai bidang kehidupan manusia yang tentunya memiliki tujuan sebagai alasan dilakukanya efisiensi kerja secara umum tujuan efisiensi kerja adalah sebagai berikut :

1) Untuk mencapai suatu hasil atau tujuan sesuai dengan yang di harapkan.

2) Untuk menghemat atau mengurangi penggunaan sumber daya dalam melakukan kegiatan.

3) Untuk memaksimalkan penggunaan segala sumber daya yang dimiliki sehingga tidak ada yang terbuang percuma.

4) Untuk meningkatkan kinerja suatu unit kerja sehingga outpunya semakin maksimal.

5) Untuk memaksimalkan keuntungan yang mungkin di dapatkan.

6) Menentukan jumlah kebutuhan pegawai (SDM) sebagai dasar untuk menambah Menentukan Jumlah Kebutuhan Pegawai/Karyawan (SDM): sebagai dasar untuk menambah atau mengurangi jumlah pegawai/karyawan pada suatu jabatan atau unit kerja.

7) Menyempurnakan (Redesign) Tugas Jabatan: menambah atau mengurangi tugas atau aktivitasaktivitas dari suatu jabatan sehingga mencapai rentang beban kerja standar (optimum).

8) Menyempurnakan (Redesign) Struktur Organisasi: menggabung 2 jabatan atau lebih menjadi 1 jabatan; memisahkan (spliting) 1 jabatan menjadi 2 atau lebih jabatan; atau menciptakan suatu jabatan baru.

9) Menyempurnakan (Redesign) Standard Operating Procedure (SOP): menyempurnakan SOP karena adanya redesign tugas/aktivitas jabatan dan/atau penyempurnaan struktur organisasi.

10) Menentukan Standar Waktu (Standard Time) Tugas dan Aktivitas: diperoleh standar waktu dari setiap tugas dan aktivitas sesuai standar normal di organisasi/perusahaan kita sendiri.

11) Menentukan Kebutuhan Pelatihan (Training Needs) Pegawai/Karyawan: yang diidentifikasi dari Waktu Normal (Normal Time) individu pegawai/karyawan yang lebih besar 
(lama) dibandingkan Waktu Standar (Standard Time) pada suatu tugas/aktivitas tertentu.

Dengan mengimplementasikan kegunaan hasil analisis beban kerja maka diharapkan organisasi/perusahaan akan dapat memperoleh tingkat efisiensi kerja yang lebih baik/tinggi dari para pegawai/karyawan, yang pada gilirannya diharapkan akan mampu meningkatkan tingkat produktivitas organisasi/ perusahaan.

Dari penjelasan diatas kita mengetahui bahwa tujuan dari berbagai upaya efisiensi adalah untuk mencapai efisiensi optimal. efisiensi optimal adalah perbandingan terbaik antara pengorbanan yang di lakukan untuk mendapatkan suatu hasil yang di harapkan.

\section{c. Jenis-jenis dan contoh efisiensi kerja}

Setelah memahami pengertian efisiensi kita juga perlu mengetahui contoh efisiensi yang sering dilakukan manusia adapun beberapa contoh efisiensi adalah sebagai berikut :

1) Efisiensi optimal adalah perbandingan terbaik antara pengorbanan yang dilakukan untuk mendapatkan suatu hasil yang di harapkan.

2) Ditinjau dari segi hasil misalnya seorang manajer dapat mencapai dari suatu output (produktifitas), yang lebih tinggi dibanding dengan masukan-masukan (tenaga kerja, uang, waktu) dan bahan yang di pakai.

3) Ditinjau dari segi penghematan. Misalnya penggunaan peralatan yang moderen maka proses kerja akan lebih cepat serta menghemat waktu dan biaya.

4) Efisiensi dengan tolak ukur adalah perbandingan antara hasil minimum yang ditentukan dengan hasil riil yang dicapai dimana lebih besar dari angaka minimum yang ditentukan. Dalam hal ini tolak ukurnya adalah kemampuan masing-masing mencapai hasil minimum yang telah ditentukan dalam waktu tertentu.

\section{Kinerja Pegawai}

a. Pengertian Kinerja pegawai

Pengertian Kinerja adalah Menurut kamus umum, kinerja adalah hasil yang dicapai dari yang telah dilakukan, dikerjakan seseorang dalam melaksanakan kerja atau tugas. Kinerja merupakan prestasi kerja atau performance, yaitu hasil kerja selama periode tertentu dibanding dengan berbagai kemungkinan.

Pengertian Kinerja pegawai adalah kesediaan seseorang atau kelompok orang untuk melakukan sesuatu kegiatan dan menyempurnakannya sesuai dengan tanggung jawabnya dengan hasil seperti yang diharapkan. Jika dikaitkan dengan performance sebagai kata benda (noun) di mana salah satu entrinya adalah hasil dari sesuatu pekerjaan (thing done), pengertian performance atau kinerja adalah hasil kerja yang dapat dicapai oleh seseorang dalam suatu perusahaan sesuai dengan wewenang dan tanggung jawab masing-masing dalam upaya pencapaian tujuan perusahaan secara legal, tidak melanggar hukum dan tidak bertentangan dengan moral atau etika (Rivai, 2009:15-17). Kinerja pegawai merupakan hasil kerja secara kualitas dan kuantitas yang dicapai oleh seorang pegawai dalam melaksanakan tugasnya sesuai dengan tanggung jawab yang diberikan kepadanya.

Berdasarkan pengertian diatas dapat disimpulkan bahwa pegawai adalah orang yang bekerja pada suatu 
tempat yang resmi, memiliki data-data pribadi dan mempunyai kekuatan hukum. Tempat pekerjaan yang dimaksud adalah organisasi, lembaga, atau badan lainnya yang berhubungan dengan pegawai.

Menurut Rivai (2010:309) konsep kinerja adalah perilaku nyata yang ditampilkan setiap orang sebagai prestasi kerja yang dihasilkan oleh karyawan sesuai dengan perannya dalam perusahaan.

Sedangkan menurut pendapat Ilyas (2011:55) mengatakan bahwa pengertian kinerja adalah penampilan, hasil karya personil baik kualitas, maupun kuantitas penampilan individu maupun kelompok kerja personil, penampilan hasil karya tidak terbatas kepada personil yang memangku jabatan fungsional maupun struktural tetapi juga kepada keseluruhan jajaran personil di dalam organisasi.

Berdasarkan dari pendapat ahli di atas maka dapat ditarik kesimpulan yakni arti kinerja merupakan hasil yang dicapai seseorang dalam melaksanakan tugas atau beban tanggung jawab menurut ukuran atau standar yang berlaku pada masing-masing organisasi.

\section{b. Penilaian Kinerja pegawai}

Penilaian kinerja pegawai atau dikenal dengan istilah "Performance appraisal", menurut pendapat A Anwar Prabu Mangkunegara (2011 : 69) mengemukakan bahwa : Penilaian pegawai merupakan evaluasi yang sistematis dari pekerjaan pegawai dan potensi yang dapat dikembangkan.

Penilaian pegawai merupakan evaluasi yang sistimatis dari pekerjaan pegawai dan potensi yang dapat dikembangkan. Penilaian adalah proses penaksiran atau penentuan nilai, kualitas, atau status dari beberapa objek, orang ataupun sesuatu.

Berdasarkan pendapat dua ahli diatas, maka dapat dikatakan bahwa penilaian kinerja adalah suatu proses penilaian kinerja pegawai yang dilakukan pimpinan perusahaan secara sistimatis berdasarkan pekerjaan yang ditugaskan kepadanya. Pemimpin perusahaan yang menilai kinerja pegawai, yaitu atasan pegawai langsung, dan atasan tak langsung. Disamping itu pula, kepala bagian personalia berhak pula memberikan penilaian prestasi terhadap semua pegawainya sesuai dengan data yang ada di bagian personalia.

Menurut Hani Handoko (2013:358), mengatakan bahwa penilaian kinerja dapat digunakan untuk:

1) Perbaikan kinerja, umpan balik pelaksanaan kerja memungkinkan, manajer dan departemen personalia dapat memperbaiki kegiatan-kegiatan mereka untuk meningkatkan prestasi

2) Penyesuaian-penyesuaian gaji, evaluasi kinerja membantu para pengambil keputusan dalam menentukan kenaikan upah, pemberian bonus dan bentuk gaji lainnya.

3) Keputusan-keputusan penempatan, promosi dan mutasi biasanya didasarkan atas kinerja masa lalu. Promosi sering merupakan bentuk penghargaan terhadap kinerja masa lalu.

4) Perencanaan kebutuhan latihan dan pengembangan, kinerja yang jelek mungkin menunjukkan perlunya latihan. Demikian juga sebaliknya, kinerja yang baik mungkin mencerminkan potensi yang harus dikembangkan.

5) Perencanaan dan pengembangan karier, umpan balik prestasi 
mengarahkan keputusan-keputusan karier, yaitu tentang jalur karier tertentu yang harus diteliti.

6) Penyimpangan-penyimpangan proses staffing, kinerja yang baik atau buruk adalah mencerminkan kekuatan atau kelemahan prosedur staffing departemen personalia.

7) Melihat ketidak akuratan informasional, kinerja yang jelek mungkin menunjukkan kesalahankesalahan dalam informasi analisis jabatan, rencana sumber daya manusia atau komponen-komponen lain, seperti sistim informasi manajemen. Menggantungkan pada informasi yang tidak akurat dapat menyebabkan keputusan-keputusan personalia yang tidak tepat.

8) Mendeteksi kesalahan-kesalahan desain pekerjaan, kinerja yang jelek mungkin merupakan suatu tanda kesalahan dalam desain pekerjaan. Penilaian prestasi membantu diagnosa kesalahan-kesalahan tersebut.

9) Menjamin kesempatan yang adil, penilaian kinerja yang akurat akan menjamin keputusan-keputusan penempatan internal diambil tanpa deskriminasi.

10) Melihat tantangan-tantangan eksternal, kadang-kadang prestasi seseorang dipengaruhi oleh faktorfaktor di luar lingkungan kerja, seperti keluarga, kesehatan dan masalahmasalah pribadi lainnya. Berdasarkan penilaian kinerja, departemen personalia mungkin dapat menawarkan bantuan.

\subsection{Kerangka Pikir}

Peningkatan tenaga kerja yang produktif sangat diprioritaskan melalui berbagai usaha untuk menumbuhkan kegairahan bekerja, maka perlu:

Gambar 2.1 Bentuk kerangka pemikiran deskriptif

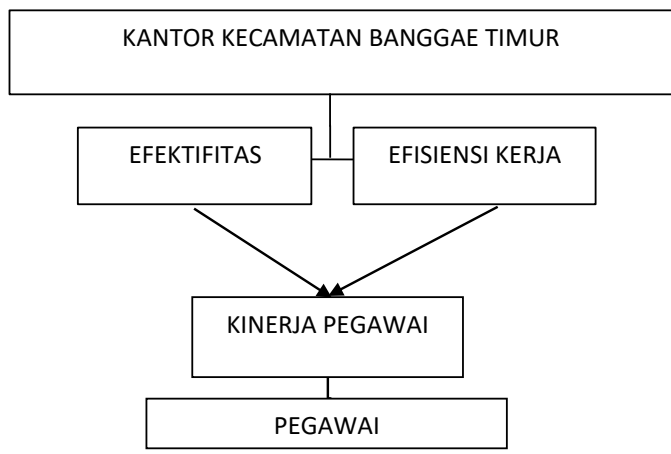

\subsection{Hipotesis}

Hipotesis merupakan dugaan sementara atas suatu hubungan, sebab akibat dari kinerja variabel yang perlu dibuktikan kebenarannya. Hipotesis dapat dibedakan dalam hipotesis deskriptif, hipotesis komparatif, dan hipotesis kuantitatif atau asosiatif yang berbentuk statistik.

a. Diduga Efektifitas berpengaruh terhadap Kinerja Pegawai pada Kantor Kecamatan Banggae Timur Kabupaten Majene

b. Diduga Efisiensi kerja berpengaruh terhadap kinerja Pegawai Pada Kantor Kecamatan Banggae Timur Kabupaten Majene

c. Diduga efektifitas lebih dominan mempengaruhi kinerja pegawai Kantor Kecamatan Banggae Timur.

\section{METODE PENELITIAN}

\subsection{Teknik Analisa Data}

Metode analisa data yang digunakan dalam penelitian ini adalah metode analisa regresi linier berganda dengan rumus sebagai berikut:

$\mathrm{Y}=\mathrm{b} 0+\mathrm{b}_{1} \mathrm{X}_{1}+\mathrm{b}_{2} \mathrm{X}_{2}+\mathrm{e}$

Dengan :

- $\mathrm{Y}=$ Kinerja Pegawai

- $\mathrm{X} 1$ = Efektifitas

- $\mathrm{X} 2$ = Efisiensi Kerja 
- $\mathrm{B} 0=$ Konstanta Regresi

- b1, b2 =Parameter Hitungan

- $\mathrm{e}=$ Penyimpanan atau Kesalahan

Tahapan yang dilakukan dalam melakukan uji hipotesis adalah sebagai berikut:

\section{a. Uji t}

Uji t digunakan untuk mengetahui pangaruh variabel independen secara parsial terhadap variabel dependen yaitu pengaruh dari masing-masing variabel independen yang terdiri atas efektifitasn dan efisiensi kerja terhadap kinerja pegawai yang merupakan variabel dependennya. Pengujian terhadap hasil regresi dilakukan dengan menggunakan uji $\mathrm{t}$ pada derajat keyakinan sebesar $95 \%$ atau $\alpha=5 \%$.

Langkah-langkahnya adalah sebagai berikut:

1) Menentukan Formula Hipotesis. Hipotesis dalam uji $t$ ini adalah Pengaruh Efektifitas terhadap kinerja pegawai :

H01: $\beta 1 \leq 0$, artinya variabel efektifitas (X1) tidak berpengaruh positif terhadap variabel kinerja pegawai (Y).

Ha1: $\beta 1>0$, artinya variabel Keterampilan (X1) berpengaruh positif terhadap kinerja pegawai (Y).

Pengaruh efisiensi kerja terhadap kinerja pegawai:

H02: $\beta 2 \leq 0$, artinya variabel efisiensi kerja (X2) tidak berpengaruh positif terhadap kinerja pegawai (Y).

Ha2: $\beta 2>0$, artinya variabel efisiensi kerja (X2) berpengaruh positif terhadap kinerja pegawai (Y).

2) Membandingkan probabilitas tingkat kesalahan thitung dengan tingkat signifikansi tertentu.

3) Membuat keputusan.

Pengambilan keputusan uji hipotesis secara parsial didasarkan pada nilai probabilitas yang didapatkan dari hasil pengolahan data melalui program SPSS sebagai berikut:

- Jika probabilitas > 0,05 maka H0 diterima

- Jika probabilitas < 0,05 maka H0 ditolak

- Uji Signifikansi Simultan (Uji F)

b. Uji F

Uji F digunakan untuk mengetahui pengaruh seluruh variabel independen yaitu efektifitas (X1) dan efisiensi kerja (X2) terhadap variabel dependen yaitu kinerja pegawai (Y). Rumusan hipotesis untuk uji $\mathrm{F}$ adalah sebagai berikut:

1) H0: $\beta 1, \beta 2=0$, artinya efektifitas dan efisiensi kerja secara simultan tidak berpengaruh terhadap kinerja pegawai. Uji $\mathrm{F}$ digunakan untuk mengetahui pengaruh seluruh variabel independen efektifitas (X1) dan efisiensi kerja (X2) terhadap variabel dependen yaitu kinerja pegawai (Y).

Rumusan hipotesis untuk uji $\mathrm{F}$ adalah H0: $\beta 1, \beta 2=0$, artinya efektifitas dan efisiensi kerja secara simultan tidak berpengaruh terhadap kinerja pegawai. Banyak peneliti menganjurkan untuk menggunakan nilai Adjusted R2 (Adjusted Square) pada saat mengevaluasi mana model regresi terbaik. Tidak seperti R2, nilai Adjusted R2 dapat naik atau turun apabila satu variabel independen ditambahkan ke dalam model. Dalam kenyataan nilai Adjusted R2 dapat bernilai negatif, walaupun yang dikehendaki harus bernilai positif (Ghozali, 2011: 98). 


\section{HASIL DAN PEMBAHASAN}

\subsection{Hasil Penelitian}

a. Karakteristik Responden

\section{Berdasarkan Jenis Kelamin}

Adapun karakteristik responden berdasarkan jenis kelamin pada Kantor Kecamatan Banggae Timur dapat dlihat pada tabel berikut ini :

Tabel 4.1Karakteristik Responden Berdasarkan Jenis Kelamin

\begin{tabular}{|c|c|c|c|}
\hline No & $\begin{array}{c}\text { Jenis } \\
\text { Kelamin }\end{array}$ & $\begin{array}{c}\text { Frekue } \\
\text { nsi }\end{array}$ & $\begin{array}{c}\text { Persent } \\
\text { ase }\end{array}$ \\
\hline 1 & Laki-laki & 22 & 56,5 \\
\hline 2 & Perempuan & 17 & 43,5 \\
\hline \multicolumn{2}{|c|}{ Total } & $\mathbf{3 9}$ & $\mathbf{1 0 0 \%}$ \\
\hline
\end{tabular}

Sumber Data 2020

Berdasarkan tabel di atas, menunjukkan bahwa dari 39 Pegawai atau responden pada penelitian ini, terdapat 22 Pegawai berjenis kelamin laki-laki dengan persentase $56,5 \%$, dan 17 pegawai berjenis kelamin Perempuan dengan persentase $43,5 \%$ sehingga dapat dinyatakan bahwa jumlah pegawai atau responden pada Kantor Kecamatan Banggae Timur yang berjenis kelamin Laki-laki lebih banyak dari jumlah responden berjenis kelamin Perempuan.

\section{b. Karakteristik}

\section{Responden}

\section{Berdasarkan Usia}

Adapun karakteristik responden berdasarkan usia pada Kantor Kecamatan Banggae Timur, dapat dilihat pada tabel di bawah ini :

Tabel 4.2 Karakteristik Responden Berdasarkan Usia

\begin{tabular}{|c|c|c|c|}
\hline No & Usia (Tahu) & Frekuensi & Persentase \\
\hline $\mathbf{1}$ & $20-30$ & 4 & 10,2 \\
\hline $\mathbf{2}$ & $31-40$ & 12 & 30,7 \\
\hline $\mathbf{3}$ & $41-50$ & 18 & 46,2 \\
\hline $\mathbf{4}$ & $>51$ & 5 & 12,9 \\
\hline \multicolumn{2}{|c|}{ Total } & $\mathbf{3 9}$ & $\mathbf{1 0 0 \%}$ \\
\hline
\end{tabular}

Sumber Data 2020
Berdasarkan data pada tabel di atas, terdapat 4 orang dengan persentase $10,2 \%$ pada usia responden antara 20 30 tahun, 12 orang dengan persentase $30,7 \%$ pada usia responden $31-40$ tahun, 18 orang dengan persentase $46,2 \%$ pada usia responden $41-50$ tahun, dan 5 orang dengan persentase $12,9 \%$ pada usia responden $>51$ tahun.

Dari data di atas dinyatakan bahwa jumlah responden yang paling banyak berdasarkan usia adalah antara 41 - 50 tahun yaitu sebanyak 18 orang dengan persentase sebesar $46,2 \%$.

\section{c. Karakteristik Responden}

Berdasarkan Pendidikan Terakhir

Adapun karakteristik responden berdasarkan pendidikan ter- akhir Pada Kantor Kecamatan Banggae Timur dapat dilihat pada tabel Berikut :

Tabel 4.3 Karakteristik Responden Berdasarkan Pendidikan Terakhir

\begin{tabular}{|c|c|c|c|}
\hline No. & Pendidikan Terakhir & Frekuensi & Persentase \\
\hline $\mathbf{1}$ & Strata Satu (S1) & 32 & 82,1 \\
\hline $\mathbf{2}$ & Strata Dua (S2) & 5 & 12,8 \\
\hline 3 & SMA & 2 & 5,1 \\
\hline \multicolumn{2}{|c|}{ Total } & 39 & $\mathbf{1 0 0 \%}$ \\
\hline
\end{tabular}

Berdasarkan pada tabel di atas bahwa terdapat 32 Pegawai dengan pendidikan terakhir S1 dengan presentase sebesar $82,1 \%$, kemudian terdapat 5 orang dengan pendidikan terakhir S2 dengan persentase sebesar $12,8 \%$, dan terdapat 2 orang dengan pendidikan terakhir SMA dengan persentase sebesar $5,1 \%$

Dari data di atas dapat dinyatakan bahwa jumlah responden yang paling banyak adalah yang berpendidikan S1 yaitu sebanyak 32 orang dengan persentase sebesar $82,1 \%$. 


\section{d. Karakteristik \\ Berdasarkan Masa Kerja}

Adapun karakteristik responden berdasarkan Masa Kerja pada Kantor Kecamatan Bangae Timur, dapat dilihat pada tabel di bawah ini :

Tabel 4.4 Karakteristik Responden Berdasarkan Masa Kerja

\begin{tabular}{|c|c|c|c|}
\hline No. & $\begin{array}{c}\text { Masa } \\
\text { Kerja }\end{array}$ & Frekuensi & $\begin{array}{c}\text { Persentas } \\
\text { e }\end{array}$ \\
\hline $\mathbf{1}$ & $\leq 10$ & 10 & 25,6 \\
\hline $\mathbf{2}$ & $\begin{array}{c}>10- \\
\leq 25\end{array}$ & 26 & 66,6 \\
\hline $\mathbf{3}$ & $>25$ & 3 & 7,8 \\
\hline \multicolumn{2}{|c|}{ Total } & $\mathbf{3 9}$ & $\mathbf{1 0 0 \%}$ \\
\hline
\end{tabular}

Tabel di atas menunjukkan hasil pengelolaan data dari 39 Pegawai atau responden penelitian pada Kantor Kecamatan Banggae Timur, bahwa terdapat 10 orang dengan masa kerja $\leq$ 10 tahun dengan persentase sebesar $25,6 \%$, kemudian terdapat 26 orang dengan masa kerja antara $>10-\leq 25$ tahun dengan persentase sebesar $66,6 \%$, dan 3 orang dengan masa kerja $>25$ tahun dengan persentase sebesar 7,8\%.

Dari data di atas dapat dinyatakan bahwa jumlah responden yang paling banyak adalah dengan masa kerja $>10-$ $\leq 25$ tahun yaitu sebanyak 26 orang atau dengan persentase sebesar $66,6 \%$.

\section{e. Tanggapan Responden Terhadap Variabel Penelitian}

Untuk menerangkan tanggapan responden terhadap variabel penelitian maka dilakukan analisis jawaban yang diberikan responden berkaitan dengan pernyataan tersebut. pernyataan terdiri atas 5 item, untuk mengetahui lebih jelas mengenai pernyataan berasal dari variabel Efektifitas, Efisiensi dan Kinerja Pegawai. Dari analisis tersebut diketahui berapa banyak responden yang memilih alternatif jawaban tertentu dan memperoleh nilai rata-rata, nilai tertinggi, sampai dengan terendah.

Untuk menerangkan tanggapan responden terhadap variabel penelitian digunakan metode rata-rata (mean) dan tabel distribusi frekuensi. Alat ukur tanggapan responden terhadap variabel penelitian adalah sebagai berikut :

Nilai Tanggapan Deskripsi

- 1,00 - 1,80 Sangat Rendah

- 1,81 - 2,60 Rendah

- 2,61 - 3,40 Cukup Tinggi

- 3,41 - 4,20 Tinggi

- 4,21 - 5,00 Sangat Tinggi

\section{f. Tanggapan Responden Terhadap Variabel Efektifitas}

Dari hasil penelitian terhadap variabel Efektifitas. Berdasarkan jumlah total skor jawaban responden atas indikator-indikator konflik, maka selanjutnya dilakukan akumulasi skor jawaban responden sebagai berikut :

Tabel 4.5

\begin{tabular}{|c|l|c|c|}
\hline $\begin{array}{c}\text { No. } \\
\text { Item }\end{array}$ & Alternatif Jawaban & Frekuensi & Persentase \\
\hline \multirow{3}{*}{1} & Sangat Setuju & 7 & 12,9 \\
\cline { 2 - 4 } & Setuju & 29 & 74,4 \\
\cline { 2 - 4 } & Kurang Setuju & 2 & 5,2 \\
\cline { 2 - 4 } & Tidak Setuju & 1 & 2,5 \\
\cline { 2 - 4 } & Sangat Tidak Setuju & 0 & 0 \\
\hline \multicolumn{2}{|c|}{ Total } & 39 & $100 \%$ \\
\hline
\end{tabular} Sumber Data 2020

Tabel di atas menunjukkan hasil pengelolaan data dari 39 Pegawai, bahwa sebanyak 7 orang atau 12,9\% memilih alternatif jawaban Sangat Setuju, sebanyak 29 orang dengan persentase sebesar 74,4\% memilih Alternatif Jawaban Setuju, sebanyak 2 orang dengan persentase sebesar 5,2\% memilih alternarif jawaban Kurang Setuju, dan sebanyak 1 orang dengan persentase sebesar 2,5\% memilih alternatif jawaban 
Sangat Tidak Setuju, sdangkan alternatif jawaban Tidak Setuju adalah $0 \%$.

Dari hasl pengelolaan data pada tabel di atas menunjukkan alternatif jawaban yang lebih dominan dipilih adalah Setuju dengan Persentase sebesar $74,4 \%$

Tabel 4.6

\begin{tabular}{|c|l|c|c|}
\hline $\begin{array}{c}\text { No. } \\
\text { Item }\end{array}$ & Alternatif Jawaban & Frekuensi & Persentase \\
\hline \multirow{3}{*}{2} & Sangat Setuju & 8 & 20,5 \\
\cline { 2 - 4 } & Setuju & 31 & 79,5 \\
\cline { 2 - 4 } & Kurang Setuju & 0 & 0 \\
\cline { 2 - 4 } & Tidak Setuju & 0 & 0 \\
\cline { 2 - 4 } & Sangat Tidak Setuju & 0 & 0 \\
\hline \multicolumn{2}{|c|}{ Total } & 39 & $100 \%$ \\
\hline
\end{tabular} Sumber Data 2020

Tabel di atas menunjukkan hasil pengelolaan data dari 39 pegawai, bahwa sebanyak 8 orang dengan persentase sebesar 20,5\% memilih alternatif jawaban Sangat Setuju, kemudian sebanyak 31 Guru dengan persentase sebesar $79,5 \%$ memilih alternatif jawaban Setuju, sedangkan alternatif jawaban Kurang setuju, Tidak Setuju dan Sangat Tidak Setuju adalah 0\%.

Dari hasil pengelolaan data pada tabel di atas menunjukkan alternatif jawaban yang lebih dominan dipilih adalah Setuju dengan Persentase sebesar $79,5 \%$

Tabel 4.7

\begin{tabular}{|c|l|c|c|}
\hline $\begin{array}{c}\text { No. } \\
\text { Item }\end{array}$ & Alternatif Jawaban & Frekuensi & Persentase \\
\hline \multirow{3}{*}{3} & Sangat Setuju & 6 & 15,3 \\
\cline { 2 - 4 } & Setuju & 21 & 53,9 \\
\cline { 2 - 4 } & Kurang Setuju & 12 & 30,8 \\
\cline { 2 - 4 } & Tidak Setuju & 0 & 0 \\
\cline { 2 - 4 } & Sangat Tidak Setuju & 0 & 0 \\
\hline \multicolumn{2}{|c|}{ Total } & 39 & $100 \%$ \\
\hline
\end{tabular}

Sumber Data 2020

Tabel di atas menunjukkan hasil pengelolaan data dari 39 Orang, bahwa sebanyak 6 orang dengan persentase sebesar $15,3 \%$ memilih alternatif jawaban Sangat Setuju, sebanyak 21 orang dengan persentase sebesar $53,9 \%$ memilih alternatif jawaban Setuju, dan sebanyak 12 orang dengan persentase sebesar 30,8\% memilih alternatif jawaban Kurang Setuju, sedangkan alternatif jawaban Tidak Setuju dan Sangat Tidak Setuju adalah 0\%.

Dari hasil pengelolaan data pada tabel di atas menunjukkan alternatif jawaban yang lebih dominan dipilih adalah Setuju. dengan Persentase sebesar $53,9 \%$.

Tabel 4.8

\begin{tabular}{|c|l|c|c|}
\hline $\begin{array}{c}\text { No. } \\
\text { Item }\end{array}$ & Alternatif Jawaban & Frekuensi & Persentase \\
\hline \multirow{3}{*}{4} & Sangat Setuju & 14 & 35,9 \\
\cline { 2 - 4 } & Setuju & 21 & 53,9 \\
\cline { 2 - 4 } & Kurang Setuju & 3 & 7,7 \\
\cline { 2 - 4 } & Tidak Setuju & 1 & 2,5 \\
\cline { 2 - 4 } & Sangat Tidak Setuju & 0 & 0 \\
\hline \multicolumn{2}{|c|}{ Total } & 39 & $100 \%$ \\
\hline
\end{tabular}

Tabel di atas menunjukkan hasil pengelolaan data dari 39 orang, bahwa sebanyak 14 Orang dengan persentase sebesar $35,9 \%$ memilih alternatif jawaban Sangat Setuju, sebanyak 21 orang dengan persentase sebesar $53,9 \%$ memilih alternatif jawaban Setuju, sebanyak 3 orang dengan persentase sebesar 7,7\% memilih alternatif jawaban Kurang Setuju, dan sebanyak 1 orang dengan persentase sebesar 2,5\% memilih alternatif jawaban Tidak Setuju, sedangkan alternatif jawaban Sangat Tidak Setuju adalah 0\%.

Dari hasil pengelolaan data pada tabel di atas menunjukkan alternatif jawaban yang dominan dipilih adalah Setuju dengan Perentase sebesar 53,9\%. 


\begin{tabular}{|c|c|c|c|}
\hline $\begin{array}{l}\text { No. } \\
\text { Item }\end{array}$ & Alternatif Jawaban & Frekuensi & Persentase \\
\hline \multirow{5}{*}{5} & Sangat Setuju & 13 & 33,3 \\
\hline & Setuju & 20 & 51,3 \\
\hline & Kurang Setuju & 5 & 12,9 \\
\hline & Tidak Setuju & 1 & 2,5 \\
\hline & Sangat Tidak Setuju & 0 & 0 \\
\hline \multicolumn{2}{|r|}{ Total } & 39 & $100 \%$ \\
\hline
\end{tabular}

Sumber Data 2020

Tabel di atas menunjukkan hasil pengelolaan data dari 39 orang bahwa sebanyak 13 orang dengan persentase sebesar $33,3 \%$ memilih alternatif jawaban Sangat Setuju, sebanyak 20 orang dengan persentase sebesar 51,3\% memilih alternatif jawaban Setuju, sebanyak 5 orang dengan persentase sebesar $12,9 \%$ memilih alternatif jawaban Kurang Setuju, sebanyak 1 orang dengan persentase sebesar 2,5\% memilih alternatif jawaban Tidak Setuju, sedangkan alternatif jawaban Sangat Tidak Setuju adalah 0\%. Dari hasil pengelolaan data pada tabel di atas menunjukkan alternatif jawaban yang lebih dominan dipilih adalah Setuju dengan Perentase sebesar 51,3\%.

Berdasarkan jumlah total skor jawaban responden atas indikatorindikator Efektifitas, maka selanjutnya dilakukan akumulasi skor jawaban responden sebagai berikut :

\section{Nilai Tanggapan Deskripsi :}

- 1,00 - 1,80 Sangat Rendah

- 1,81-2,60 Rendah

- 2,61 - 3,40 Cukup Tinggi

- 3,41-4,20 Tinggi

- 4,21 - 5,00 Sangat Tinggi

Tabel 4.1.0 Rata-rata Penilaian Terhadap Variabel Efektifitas $\left(\mathrm{X}_{1}\right)$

\begin{tabular}{|c|c|c|c|c|c|c|c|c|c|}
\hline \multirow{2}{*}{$\begin{array}{l}\text { No. } \\
\text { Item }\end{array}$} & \multicolumn{5}{|c|}{ Frekuensi Jawaban } & \multirow{2}{*}{$\mathrm{N}=42$} & \multirow{2}{*}{$\begin{array}{c}\text { Jumlah } \\
\text { skor }\end{array}$} & \multirow{2}{*}{ Mean } & \multirow{2}{*}{ Penilaian } \\
\hline & STS & TS & KS & S & SS & & & & \\
\hline 1 & 1 & 2 & 6 & 116 & 35 & 39 & 160 & 4,10 & Tinggi \\
\hline 2 & 0 & 0 & 0 & 124 & 40 & 39 & 164 & 4,20 & Tinggi \\
\hline 3 & 0 & 0 & 36 & 84 & 30 & 39 & 150 & 3,84 & Tinggi \\
\hline 4 & 0 & 2 & 9 & 84 & 70 & 39 & 165 & 4,23 & Sangat Tinggi \\
\hline 5 & 0 & 2 & 15 & 80 & 65 & 39 & 162 & 4,15 & Tinggi \\
\hline \multicolumn{8}{|c|}{ Rata-rata Konflik } & 4,10 & Tinggi \\
\hline
\end{tabular}

\section{Sumber Data 2020}

Hasil perhitungan pada tabel di atas menunjukkan bahwa Kompetensi masuk kedalam kriteria Tinggi, hal ini dapat dilihat dari skor rata-rata yang dihasilkan sebesar 4,10 dan berdasarkan rentang skor rata-rata berada pada interval 3,41 - 4,20 yang berarti masuk dalam klasifikasi penilaian Tinggi. 
g. Tanggapan Responden Terhadap

\section{Variabel Efisiensi Kerja $\left(X_{2}\right)$}

Pada hasil penelitian terhadap variabel Efisiensi Kerja pada Kantor Kecamatan Banggae Timur, Berdasarkan

Tabel 4.1.1

\begin{tabular}{|c|c|c|c|}
\hline No. Item & Alternatif Jawaban & Frekuensi & Persentase \\
\hline \multirow{3}{*}{$\mathbf{1}$} & Sangat Setuju & 9 & 23,2 \\
\cline { 2 - 4 } & Setuju & 23 & 58,9 \\
\cline { 2 - 4 } & Kurang Setuju & 5 & 12,9 \\
\cline { 2 - 4 } & Tidak Setuju & 2 & 5 \\
\cline { 2 - 4 } & Sangat Tidak Setuju & 0 & 0 \\
\hline \multicolumn{1}{|c|}{ Total } & $\mathbf{3 9}$ & $\mathbf{1 0 0} \%$ \\
\hline
\end{tabular}

\section{Sumber Data 2020}

Tabel di atas menunjukkan hasil pengelolaan data dari 39 orang, bahwa sebanyak 9 orang dengan persentase 23,2\% memilih alternatif jawaban Sangat Setuju, sebanyak 23 orang dengan persentase $58,9 \%$ memilih alternatif jawaban Setuju, sebanyak 5 orang dengan persentase $12,9 \%$ memilih alternatif jawaban Kurang Setuju, dan jumlah total skor jawaban responden atas indikator-indikator konflik, maka selanjutnya dilakukan akumulasi skor jawaban responden sebagai berikut :

\section{Tabel 4.1.2}

\begin{tabular}{|c|c|c|c|}
\hline \multirow{2}{*}{ No. Item } & Alternatif Jawaban & Frekuensi & Persentase \\
\hline \multirow{3}{*}{2} & Sangat Setuju & 11 & 28,2 \\
\cline { 2 - 4 } & Setuju & 25 & 64,1 \\
\cline { 2 - 4 } & Kurang Setuju & 3 & 7,7 \\
\cline { 2 - 4 } & Tidak Setuju & 0 & 0 \\
\cline { 2 - 4 } & Sangat Tidak Setuju & 0 & 0 \\
\hline \multirow{2}{*}{ Total } & $\mathbf{3 9}$ & $\mathbf{1 0 0} \%$ \\
\hline
\end{tabular}

\section{Sumber Data 2020}

Tabel di atas menunjukkan hasil pengelolaan data dari 39 orang, bahwa sebanyak 11 orang dengan persentase sebesar 28,2\% memilih alternatif jawaban Sangat Setuju, sebanyak 25 sebanyak 2 orang dengan persentase $5 \%$ memilih alternatif jawaban Tidak Setuju, sedangkan alternatif jawaban Sangat Tidak Setuju adalah $0 \%$.

Dari hasil pengelolaan data pada tabel di atas menunjukkan alternatif jawaban yang lebih dominan dipilih adalah Setuju dengan Persentase sebesar $58,9 \%$. orang dengan persentase sebesar $64,1 \%$ memilih alternatif jawaban Setuju, dan sebanyak 3 orang dengan persentase sebesar 7,7\% memilih alternatif jawaban Kurang Setuju, sedangkan alternatif 
jawaban Tidak Setuju dan Sangat Tidak Setuju adalah $0 \%$.

Dari hasil pengelolaan data pada tabel di atas menunjukkan alternatif jawaban yang lebih dominan dipilih adalah Setuju dengan persentase $64,1 \%$.

Tabel 4.1.3

\begin{tabular}{|c|c|c|c|}
\hline No. Item & Alternatif Jawaban & Frekuensi & Persentase \\
\hline \multirow{3}{*}{3} & Sangat Setuju & 14 & 35,9 \\
\cline { 2 - 4 } & Setuju & 20 & 51,2 \\
\cline { 2 - 4 } & Kurang Setuju & 5 & 12,9 \\
\cline { 2 - 4 } & Tidak Setuju & 0 & 0 \\
\cline { 2 - 4 } & Sangat Tidak Setuju & 0 & 0 \\
\hline \multicolumn{2}{|c|}{ Total } & $\mathbf{3 9}$ & $\mathbf{1 0 0} \%$ \\
\hline
\end{tabular}

\section{Sumber Data 2020}

Tabel di atas menunjukkan hasil pengelolaan data dari 39 orang, bahwa sebanyak 14 orang dengan persentase 35,9\% memilih alternatif jawaban Sangat Setuju, sebanyak 20 orang dengan persentase sebesar 51,2\% memilih alternatif jawaban Setuju, sebanyak 5 orang dengan persentase sebesar 12,9\% memilih alternatif jawaban Kurang
Setuju, sedangkan alternatif jawaban Tidak Setuju dan Sangat Tidak Setuju adalah $0 \%$.

Dari hasil pengelolaan data pada tabel di atas menunjukkan alternatif jawaban yang lebih dominan dipilih adalah Setuju dengan persentase sebesar $51,2 \%$.

Tabel 4.1.4

\begin{tabular}{|c|c|c|c|}
\hline \multirow{2}{*}{ No. Item } & Alternatif Jawaban & Frekuensi & Persentase \\
\hline \multirow{4}{*}{4} & Sangat Setuju & 7 & 17,9 \\
\cline { 2 - 4 } & Setuju & 24 & 61,6 \\
\cline { 2 - 4 } & Kurang Setuju & 8 & 20,5 \\
\cline { 2 - 4 } & Tidak Setuju & 0 & 0 \\
\hline \multicolumn{2}{|c|}{ Sangat Tidak Setuju } & $\mathbf{3 9}$ & $\mathbf{1 0 0 \%}$ \\
\hline
\end{tabular}

\section{Sumber Data 2020}

Tabel di atas menunjukkan hasil pengelolaan data dari 39 orang, bahwa sebanyak 7 orang dengan persentase sebesar $17,9 \%$ memilih alternatif jawaban Sangat Setuju, dan sebanyak 24 orang dengan persentase sebesar $61,6 \%$ memilih alternatif jawaban Setuju, dan sebanyak 8 orang dengan persentase sebanyak $20,5 \%$ memilih alternatif jawaban Kurang Setuju, sedangkan alternatif jawaban Tidak Setuju dan Sangat Tidak Setuju adalah 0\%. Dari hasil pengelolaan data pada tabel di atas menunjukkan alternatif jawaban yang dominan dipilih adalah Setuju dengan Persentase sebesar $61,6 \%$. 
Tabel 4.1.5

\begin{tabular}{|c|c|c|c|}
\hline No. Item & Alternatif Jawaban & Frekuensi & Persentase \\
\hline \multirow{5}{*}{5} & Sangat Setuju & 13 & 33,3 \\
\hline & Setuju & 21 & 53,9 \\
\hline & Kurang Setuju & 3 & 7,7 \\
\hline & Tidak Setuju & 2 & 5,1 \\
\hline & Sangat Tidak Setuju & 0 & 0 \\
\hline \multicolumn{2}{|r|}{ Total } & 39 & $100 \%$ \\
\hline
\end{tabular}

\section{Sumber Data 2020}

Tabel di atas menunjukkan hasil pengelolaan data dari 39 orang, bahwa sebanyak 13 orang dengan persentase sebesar 33,3\% memilih alternatif jawaban Sangat Setuju, sebanyak 21 orang dengan persentase sebesar 53,9\% memilih alternatif jawaban Setuju, sebanyak 3 orang dengan persentase sebesar 7,7 memilih alternatif jawaban kurang setuju, dan sebanyak 2 orang dengan persentase sebesar 5,1\% memilih alternatif jawaban Tidak Setuju, sedangkan alternatif jawaban Sangat Tidak Setuju adalah 0\%.
Dari hasil pengelolaan data pada tabel di atas menunjukkan bahwa alternatif jawaban yang lebih dominan dipilih adalah Setuju dengan Persentase sebesar 53,9\%. Berdasarkan jumlah total skor jawaban responden atas indikatorindikator efisiensi kerja, maka selanjutnya dilakukan akumulasi skor jawaban responden sebagai berikut :.

\section{Nilai Tanggapan Deskripsi}

- 1,00 - 1,80 Sangat Rendah

- 1,81-2,60 Rendah

- 2,61 -3,40 Cukup Tinggi

- 3,41-4,20 Tinggi

- 4,21 - 5,00 Sangat Tinggi

Tabel 4.1.6 Rata-rata Penilaian Terhadap Variabel Efisiensi Kerja $\left(X_{2}\right)$

\begin{tabular}{|c|c|c|c|c|c|c|c|c|c|}
\hline \multirow{2}{*}{$\begin{array}{l}\text { No. } \\
\text { Item }\end{array}$} & \multicolumn{5}{|c|}{ Frekuensi Jawaban } & \multirow{2}{*}{$N=39$} & \multirow{2}{*}{$\begin{array}{c}\text { Jumlah } \\
\text { skor }\end{array}$} & \multirow{2}{*}{ Mean } & \multirow{2}{*}{ Penilaian } \\
\hline & STS & TS & KS & S & SS & & & & \\
\hline 1 & 1 & 4 & 15 & 92 & 45 & 39 & 156 & 4,00 & Tinggi \\
\hline 2 & 0 & 0 & 9 & 100 & 55 & 39 & 164 & 4,20 & Tinggi \\
\hline 3 & 0 & 0 & 15 & 80 & 70 & 39 & 165 & 4,23 & Sangat Tinggi \\
\hline 4 & 0 & 0 & 24 & 96 & 35 & 39 & 155 & 3,97 & Tinggi \\
\hline 5 & 0 & 4 & 9 & 84 & 65 & 39 & 162 & 4,15 & Tinggi \\
\hline \multicolumn{8}{|c|}{ Rata-rata Konflik } & 4,11 & Tinggi \\
\hline
\end{tabular}

Hasil perhitungan pada tabel di atas menunjukkan bahwa Variabel Efisiensi Kerja masuk kedalam kriteria
Tinggi, hal ini dapat dilihat dari skor rata-rata yang dihasilkan sebesar 4,11 dan berdasarkan rentang skor rata-rata berada pada interval $3,41-4,20$ yang 
berarti masuk dalam klasifikasi Penilaian

Tinggi.

\section{h. Tanggapan Responden Terhadap Variabel Kinerja Pegawai (Y)}

Dari hasil penelitian terhadap variabel Kinerja Pegawai Pada Kantor
Kecamatan Banggae Timur, berdasarkan jumlah total skor jawaban responden atas indikator-indikator konflik, maka selanjutnya dilakukan akumulasi skor jawaban responden sebagai berikut :

Tabel 4.1.7

\begin{tabular}{|c|c|c|c|}
\hline No. Item & Alternatif Jawaban & Frekuensi & Persentase \\
\hline \multirow{5}{*}{1} & Sangat Setuju & 24 & 61,6 \\
\hline & Setuju & 15 & 38,4 \\
\hline & Kurang Setuju & 0 & 0 \\
\hline & Tidak Setuju & 0 & 0 \\
\hline & Sangat Tidak Setuju & 0 & 0 \\
\hline \multicolumn{2}{|r|}{ Total } & 39 & $100 \%$ \\
\hline
\end{tabular}

\section{Sumber Data 2020}

Tabel di atas menunjukkan hasil pengelolaan data dari 39 orang, bahwa sebanyak 24 Guru dengan persentase $61,6 \%$ memilih alternatif jawaban Sangat Setuju, sebanyak 15 dengan persentase sebesar $38,4 \%$ memilih alternatif jawaban Setuju, sedangkan alternatif jawaban Kurang Setuju, Tidak Setuju dan Sangat Tidak Setuju adalah 0\%.

Dari hasil pengelolaan data pada tabel di atas menunjukkan alternatif jawaban yang lebih dominan dipilih adalah Sangat Setuju dengan Persentase sebesar $61,6 \%$.

Tabel 4.1.8

\begin{tabular}{|c|c|c|c|}
\hline \multirow{2}{*}{ No. Item } & Alternatif Jawaban & Frekuensi & Persentase \\
\hline \multirow{3}{*}{2} & Sangat Setuju & 34 & 87,1 \\
\cline { 2 - 4 } & Setuju & 5 & 12,9 \\
\cline { 2 - 4 } & Kurang Setuju & 0 & 0 \\
\cline { 2 - 4 } & Tidak Setuju & 0 & 0 \\
\cline { 2 - 4 } & Sangat Tidak Setuju & 0 & 0 \\
\hline \multirow{2}{*}{ Total } & $\mathbf{3 9}$ & $\mathbf{1 0 0 \%}$ \\
\hline
\end{tabular}

\section{Sumber Data 2020}

Tabel di atas menunjukkan hasil pengelolaan data dari 39 orang, bahwa sebanyak 34 orang dengan persentase sebesar $87,1 \%$ memilih alternatif jawaban Sangat Setuju, sebanyak 5 orang dengan persentase sebesar 12,9\% memilih alternatif jawaban Setuju, sedangkan alternatif jawaban Kurang Setuju, Tidak Setuju dan Sangat Tidak Setuju adalah $0 \%$. 
Dari hasil pengelolaan data pada tabel di atas menunjukkan alternatif jawaban yang lebih dominan dipilih adalah Sangat Setuju dengan Persentase sebesar $87,1 \%$

Tabel 4.1.9

\begin{tabular}{|c|c|c|c|}
\hline No. Item & Alternatif Jawaban & Frekuensi & Persentase \\
\hline \multirow{3}{*}{3} & Sangat Setuju & 26 & 66,7 \\
\cline { 2 - 4 } & Setuju & 13 & 33,3 \\
\cline { 2 - 4 } & Kurang Setuju & 0 & 0 \\
\cline { 2 - 4 } & Tidak Setuju & 0 & 0 \\
\cline { 2 - 4 } & Sangat Tidak Setuju & 0 & 0 \\
\hline \multirow{2}{*}{ Total } & $\mathbf{3 9}$ & $\mathbf{1 0 0 \%}$ \\
\hline
\end{tabular}

\section{Sumber Data 2020}

Tabel di atas menunjukkan hasil pengelolaan data dari Pegawai atau responden penelitian, bahwa sebanyak 26 orang dengan persentase sebesrar $66,7 \%$ memilih alternatif jawaban Sangat Setuju, sebanyak 13 orang dengan persentase sebesar 33,3\% memilih alternatif jawaban Setuju, sedangkan alternatif jawaban Kurang Setuju, Tidak Setuju dan Sangat Tidak Setuju adalah $0 \%$. Dari hasil pengelolaan data pada tabel di atas menunjukkan alternatif jawaban yang lebih dominan dipilih adalah Sangat Setuju dengan Persentase sebesar $66,7 \%$

Tabel 4.2.0

\begin{tabular}{|c|c|c|c|}
\hline \multirow{2}{*}{ No. Item } & Alternatif Jawaban & Frekuensi & Persentase \\
\hline \multirow{4}{*}{4} & Sangat Setuju & 18 & 46,1 \\
\cline { 2 - 4 } & Setuju & 21 & 53,9 \\
\cline { 2 - 4 } & Kurang Setuju & 0 & 0 \\
\cline { 2 - 4 } & Tidak Setuju & 0 & 0 \\
\cline { 2 - 4 } & Sangat Tidak Setuju & $\mathbf{3 9}$ & $\mathbf{1 0 0 \%}$ \\
\hline
\end{tabular}

\section{Sumber Data 2020}

Tabel di atas menunjukkan hasil pengelolaan data dari 39 Orang atau responden, bahwa sebanyak 18 orang dengan persentase sebesar 46,1\% memilih alternatif jawaban Sangat Setuju, sebanyak 21 orang dengan persentase sebesar 53,9\% memilih alternatif jawaban Setuju, sedangkan alternatif jawaban Kurang Setuju, Tidak Setuju dan Sangat Tidak Setuju adalah $0 \%$.

Dari hasil pengelolaan data pada tabel di atas menunjukkan alternatif jawaban yang lebih dominan dipilih adalah Setuju dengan Persentase sebesar $53,9 \%$. 
Tabel 4.2.1

\begin{tabular}{|c|c|c|c|}
\hline No. Item & Alternatif Jawaban & Frekuensi & Persentase \\
\hline \multirow{3}{*}{5} & Sangat Setuju & 17 & 43,5 \\
\cline { 2 - 4 } & Setuju & 22 & 56,5 \\
\cline { 2 - 4 } & Kurang Setuju & 0 & 0 \\
\cline { 2 - 4 } & Tidak Setuju & 0 & 0 \\
\cline { 2 - 4 } & Sangat Tidak Setuju & 0 & 0 \\
\hline \multicolumn{2}{|c}{} & $\mathbf{3 9}$ & $\mathbf{1 0 0 \%}$ \\
\hline
\end{tabular}

\section{Sumber Data 2020}

Tabel di atas menunjukkan hasil pengelolaan data dari 39 orang, bahwa sebanyak 17 orang dengan persentase sebesar $43,5 \%$ memilih alternatif jawaban Sangat Setuju, dan sebanyak 22 orang dengan persentase 56,5\% memilih alternatif jawaban Setuju, sedangkan alternatif jawaban Kurang Setuju, Tidak Setuju dan Sangat Tidak Setuju adalah $0 \%$.

Dari hasil pengelolaan data pada tabel di atas menunjukkan alternatif jawaban yang lebih dominan dipilih adalah Setuju dengan Persentase sebesar $56,5 \%$.

Berdasarkan jumlah total skor jawaban responden atas indikatorindikator kinerja guru, maka selanjutnya dilakukan akumulasi skor jawaban responden sebagai berikut :

Nilai Tanggapan Deskripsi

- 1,00 - 1,80 Sangat Rendah

- 1,81 - 2,60 Rendah

- 2,61 - 3,40 Cukup Tinggi

- 3,41 - 4,20 Tinggi

$\bullet$ 4,21 - 5,00 Sangat Tinggi

Tabel 4.2.2 Rata-rata Penilaian Terhadap Variabel Kinerja Pegawai (Y)

\begin{tabular}{|c|c|c|c|c|c|c|c|c|c|}
\hline \multirow{2}{*}{$\begin{array}{l}\text { No. } \\
\text { Item }\end{array}$} & \multicolumn{5}{|c|}{ Frekuensi Jawaban } & \multirow{2}{*}{$\mathrm{N}=39$} & \multirow{2}{*}{$\begin{array}{c}\text { Jumlah } \\
\text { skor }\end{array}$} & \multirow{2}{*}{ Mean } & \multirow{2}{*}{ Penilaian } \\
\hline & STS & TS & KS & S & SS & & & & \\
\hline 1 & 1 & 0 & 0 & 60 & 120 & 39 & 180 & 4,61 & Sangat Tinggi \\
\hline 2 & 0 & 0 & 0 & 20 & 170 & 39 & 190 & 4,87 & Sangat Tinggi \\
\hline 3 & 0 & 0 & 0 & 52 & 130 & 39 & 182 & 4,66 & Sangat Tinggi \\
\hline 4 & 0 & 0 & 0 & 84 & 90 & 39 & 174 & 4,46 & Sangat Tinggi \\
\hline 5 & 0 & 0 & 0 & 88 & 85 & 39 & 173 & 4,43 & Sangat Tinggi \\
\hline \multicolumn{8}{|c|}{ Rata-rata Konflik } & 4,60 & Sangat Tinggi \\
\hline
\end{tabular}


Hasil perhitungan pada tabel di atas menunjukkan bahwa Variabel Kinerja Pegawai masuk kedalam kriteria Sangat Tinggi, hal ini dapat dilihat dari skor rata-rata yang dihasilkan sebesar 4,60 dan berdasarkan rentang skor ratarata berada pada interval 4,21 - 5,00 yang berarti masuk dalam klasifikasi penilaian Sangat Tinggi.

i. Deskripsi Uji Validitas dan Uji Reliabelitas

1) Hasil Uji Validitas Efektifitas $\left(X_{1}\right)$

Tabel 4.1.7

\begin{tabular}{|c|c|c|c|}
\hline No. Item & $\mathbf{r}_{\text {hitung }}$ & $\mathbf{r}_{\text {tabel }}$ & Keterangan \\
\hline $\mathbf{1}$ & 0,536 & 0,316 & Valid \\
\hline $\mathbf{2}$ & 0,435 & 0,316 & Valid \\
\hline $\mathbf{3}$ & 0,547 & 0,316 & Valid \\
\hline $\mathbf{4}$ & 0,700 & 0,316 & Valid \\
\hline $\mathbf{5}$ & 0,515 & 0,316 & Valid \\
\hline
\end{tabular}

Sumber : Hasil Kuesioner diolah 2020

Hasil perhitungan diatas menunjukkan bahwa semua item pertanyaan dari variabel Efektifitas $\left(\mathrm{X}_{1}\right)$ adalah valid karena mempunyai nilai $r$ hitung $>r$ tabel $(0,316)$.

2) Hasil Uji Validitas Variabel Efisiensi Kerja $\left(\mathrm{X}_{2}\right)$

Tabel 4.1.8

\begin{tabular}{|l|l|l|l|}
\hline No. Item & $\mathbf{r}_{\text {hitung }}$ & $\mathbf{r}_{\text {tabel }}$ & Keterangan \\
\hline $\mathbf{1}$ & 0,457 & 0,316 & Valid \\
\hline $\mathbf{2}$ & 0,395 & 0,316 & Valid \\
\hline $\mathbf{3}$ & 0,617 & 0,316 & Valid \\
\hline $\mathbf{4}$ & 0,497 & 0,316 & Valid \\
\hline $\mathbf{5}$ & 0,650 & 0,316 & Valid \\
\hline
\end{tabular}

Sumber : Hasil Kuesioner diolah 2020

Hasil perhitungan diatas menunjukkan bahwa semua item pertanyaan dari variabel Efisiensi Kerja
$\left(\mathrm{X}_{2}\right)$ adalah valid karena mempunyai nilai $r$ hitung $>r$ tabel $(0,316)$.

3) Hasil Uji Validitas Variabel Kinerja Pegawai (Y)

Tabel 4.1.8

\begin{tabular}{|l|l|l|l|}
\hline No. Item & $\mathbf{r}_{\text {hitung }}$ & $\mathbf{r}_{\text {tabel }}$ & Keterangan \\
\hline $\mathbf{1}$ & 0,475 & 0,316 & Valid \\
\hline $\mathbf{2}$ & 0,513 & 0,316 & Valid \\
\hline $\mathbf{3}$ & 0,585 & 0,316 & Valid \\
\hline $\mathbf{4}$ & 0,430 & 0,316 & Valid \\
\hline $\mathbf{5}$ & 0,387 & 0,316 & Valid \\
\hline
\end{tabular}

Sumber : Hasil Kuesioner diolah 2020

Hasil perhitungan diatas menunjukkan bahwa semua item pertanyaan dari variabel Kinerja pegawai adalah valid karena mempunyai nilai $r$ hitung $>r$ tabel $(0,316)$.

4) Uji Reliabelitas

\section{Tabel 4.1.9 Reliability Statistics}

\begin{tabular}{|l|l|l|l|l|}
\hline Variabel & $\begin{array}{l}\text { Number } \\
\text { Of } \\
\text { Items }\end{array}$ & $\begin{array}{l}\text { Cronbach's } \\
\text { Alpha }\end{array}$ & $\begin{array}{l}\text { Cutt } \\
\text { off }\end{array}$ & Keputusan \\
\hline Efektifitas & 5 & 0,700 & 0,600 & Reliabel \\
\hline $\begin{array}{l}\text { Efisiensi } \\
\text { Kerja }\end{array}$ & 5 & 0,683 & 0,600 & Reliabel \\
\hline $\begin{array}{l}\text { Kinerja } \\
\text { Pegawai }\end{array}$ & 5 & 0,628 & 0,600 & Reliabel \\
\hline
\end{tabular}

Sumber : Hasil Kuesioner diolah 2020

Nilai reabilitas instrument variabel Efektifitas dengan 5 pertanyaan diperoleh nilai alpha cronbach sebesar 0,600, instrument variabel Efisiensi Kerja dengan 5 pertanyaan diperoleh nilai alpha cronbach sebesar 0,683, kemudian instrument variabel Kinerja Pegawai dengan 5 pertanyaan diperoleh nilai alpha cronbach sebesar 0,628.

Karena koefisien reabilitas ketiga instrument tersebut lebih besar dari angka penguji 0,600, maka hasil pengujian reabilitas instrument veriabel 
tersebut dapat dinyatakan reabel atau dapat diandalkan.

\section{j. Analisis Inferensial}

1) Uji Prasyarat Analisis Regresi Linear Berganda
Hasil analisis regresi berganda menggunakan bantuan program SPSS for windows dapat dilihat pada lampiran. secara lebih jelas hasil pengujian normalitas dapat dilihat pada Tabel 4.1.9 berikut :

\section{Coefficients $^{\mathrm{a}}$}

\begin{tabular}{|c|c|c|c|c|c|c|}
\hline \multirow{2}{*}{\multicolumn{2}{|c|}{ Model }} & \multicolumn{2}{|c|}{$\begin{array}{c}\text { Unstandardized } \\
\text { Coefficients }\end{array}$} & \multirow{2}{*}{$\begin{array}{c}\begin{array}{c}\text { Standardized } \\
\text { Coefficients }\end{array} \\
\text { Beta }\end{array}$} & \multirow[b]{2}{*}{$\mathrm{t}$} & \multirow[b]{2}{*}{ Sig. } \\
\hline & & B & Std. Error & & & \\
\hline \multirow[t]{3}{*}{1} & (Constant) & 13.914 & 1.897 & & 7.334 & .000 \\
\hline & Efektifitas & .335 & .089 & .545 & 3.765 & .001 \\
\hline & Efisiensi & .110 & .091 & .175 & 1.207 & .235 \\
\hline
\end{tabular}

a. Dependent Variable: Kinerja_Pegawai

Berdasarkan pada hasil perhitungan uji asumsi klasik dapat dikatakan bahwa model persamaan $\mathrm{Y}=13.914+0,335 \mathrm{X}_{1}+0,110 \mathrm{X}_{2}$ sudah masuk dalam kategori Best Linear Unbias Estimator sehingga model regresi tersebut dapat digunakan untuk memprediksi dalam penelitian ini.

Persamaan tersebut menunjukkan bahwa arah garis tersebut linier dan merupakan hubungan yang positif. Atau dengan kata lain bahwa ada pengaruh Efektifitas, Efisiensi Kerja terhadap kinerja Pegawai Kecamatan Banggae Timur.

Secara lebih rinci model regresi tersebut mengandung makna sebagai berikut :

- Konstanta sebesar 13.914 artinya jika Efektifitas $\left(\mathrm{X}_{1}\right)$, Efisiensi Kerja $\left(\mathrm{X}_{2}\right)$ nilainya 0, maka Kinerja Pegawai (Y) nilainya 13.914

- Koefisien Regresi Variavel Efektifitas $\left(\mathrm{X}_{1}\right)$ sebesar 0,335 , artinya jika variabel Efektifitas $\left(\mathrm{X}_{1}\right)$ mengalami kenaikan 1 satuan dan Efisiensi Kerja $\left(\mathrm{X}_{2}\right)$ tetap, maka kinerja Pegawai (Y) akan mengalami peningkatan sebesar 0,335. koefisien bernilai positif artinya terjadi hubungan positif antara Efektifitas dan Kinerja Pegawai.

- Koefisien Regresi Variabel Efisiensi Kerja $\left(\mathrm{X}_{2}\right)$ sebesar 0,110 artinya jika variabel Efektifitas $\left(\mathrm{X}_{1}\right)$ mengalami kenaikan 1 satuan dan Efisiensi Kerja $\left(\mathrm{X}_{2}\right)$ tetap, maka kinerja Pegawai $(\mathrm{Y})$ akan mengalami peningkatan sebesar 0,110 . koefisien bernilai positif artinya terjadi hubungan positif antara Efisiensi Kerja dan Kinerja Pegawai.

\section{k. Uji Hipotesis}

1) Uji Parsial (Uji t)

Uji ini digunakan untuk mengetahui adanya Efektifitas ( $\left.\mathrm{X}_{1}\right)$ terhadap Kinerja Pegawai Kecamatan Banggae Timur, Kabupaten Majene. Pengujian secara parsial ini dilihat pada lampiran, dan untuk lebih jelasnya dapat dilihat pada Tabel 4.2.0 output SPSS windows.

Berdasarkan hasil perhitungan pada tabel di atas menunjukkan bahwa untuk variabel Efektifitas diperoleh $t_{\text {hitung }}$ $=3,265$ dengan harga signifikan 0,001 karena harga signifikansi yang diperoleh 
kurang dari $0,05 \quad(0,001<0,05)$ maka menunjukkan bahwa nilai $t$ yang diperoleh tersebut signifikan, hal ini berarti bahwa variabel Efektifitas $\left(\mathrm{X}_{1}\right)$ berpengaruh terhadap Kinerja Pegawai (Y) maka $\mathrm{H}_{1}$ diterima.

\section{Uji Parsial (Uji t)}

Uji ini digunakan untuk mengetahui adanya Efisiensi Kerja $\left(\mathrm{X}_{2}\right)$ terhadap Kinerja Pegawai Kecamatan Banggae Timur, Kabupaten Majene. Pengujian secara parsial ini pada dilihat pada lampiran, dan untuk lebih jelasnya dapat dilihat pada Tabel 4.2.0 output SPSS windows.

Berdasarkan hasil perhitungan pada tabel di atas, menunjukkan bahwa untuk variabel Efisiensi Kerja diperoleh $t_{\text {hitung }}=1,207$ dengan harga signifikan 0,235 karena harga signifikansi yang diperoleh kurang dari $0,05(0,235<0,05)$ maka menunjukkan bahwa nilai $t$ yang diperoleh tersebut signifikan , hal ini berarti bahwa variabel Efisiensi Kerja $\left(\mathrm{X}_{2}\right)$ berpengaruh terhadap Kinerja Pegawai (Y) maka $\mathrm{H}_{2}$ diterima.

\section{Koefisien Determinasi Parsial $\left(\mathrm{r}^{2}\right)$} Derajat hubungan antara Efektifitas, Efisiensi kerja dan Kinerja Pegawai secara bersama-sama atau secara simultan dapat diketahui dari harga korelasi simultan atau $\mathrm{R}$. Berdasarkan hasil analisis dengan menggunakan program SPSS for windows release diperoleh hasil sebagai berikut :

Tabel 4.2.1 Analisis Regresi Linier Berganda

Model Summary

\begin{tabular}{|l|r|r|r|l|}
\hline Model & \multicolumn{1}{|c|}{$\mathrm{R}$} & R Square & $\begin{array}{c}\text { Adjusted R } \\
\text { Square }\end{array}$ & \multicolumn{1}{c|}{ Std. Error of the Estimate } \\
\hline 1 & $.648^{\mathrm{a}}$ & .419 & .387 & .860 \\
\hline
\end{tabular}

a. Predictors: (Constant), Efisiensi, Efektifitas

Berdasarkan dari tabel di atas, menunjukkan bahwa harga koefisien korelasi secara simultan (R) sebesar 0,648. besarnya pengaruh Efektifitas dan efiiensi Kerja dengan Kinerja Pegawai dapat diketahui dari harga koefisien determinasi simultan $\left(R^{2}\right)$ 0,419.

Dengan demikian menunjukkan bahwa Efektifitas dan Efisiensi Kerja secara bersama-sama mempengaruhi Kinerja Pegawai.

\subsection{Pembahasan}

\section{a. Pengaruh Efektifitas Terhadap} Kinerja Pegawai Pada Kantor Kecamatan Banggae Timur Kabupaten Majene

Koefisien regresi sebesar 0,335 dengan sig. pada 0,001 menunjukkan adanya pengaruh yang signifikan antara
Efektifitas terhadap Kinerja Pegawai Pada Kantor Kecamatan Banggae Timur Kabupaten Majene. Dengan demikian, hipotesis yang berbunyi "Ada pengaruh signifikan Efektifitas terhadap Kinerja Pegawai Pada Kantor Kecamatan Banggae Timur Kabupaten Majene" diterima.

b. Pengaruh Efisiensi Kerja Terhadap Kinerja Pegawai Pada Kantor Kecamatan Banggae Timur Kabupaten Majene

Koefisien regresi sebesar 0,110 dengan sig. pada 0,235 menunjukkan adanya pengaruh yang signifikan antara Efisiensi Kerja terhadap Kinerja Pegawai. Dengan demikian, hipotesis yang berbunyi "Ada pengaruh signifikan Efisiensi Kerja terhadap Kinerja Pegawai 
Pada Kantor Kecamatan Banggae Timur Kabupaten Majene" bisa diterima.

\section{c. Pengaruh Kinerja Pegawai Terhadap Kinerja Pegawai Pada Kantor Kecamatan Banggae timur Kabupaten Majene}

Berdasarkan analisis korelasi berganda, dapat diketahui bahwa variabel Efektifitas $\left(\mathrm{X}_{1}\right)$ dan Efisiensi Kerja $\left(\mathrm{X}_{2}\right)$ berpengaruh secara simultan dan bersignifikan dilihat dari hasil uji $\mathrm{F}$ 12,996. Hasil penelitian ini mengindikasikan bahwa semakin tinggi Efektifitas dan Efisiensi Kerja dalam instansi, akan diikuti oleh semakin tingginya Kinerja Pegawai.

\section{PENUTUP}

\subsection{Simpulan}

Berdasarkan hasil penelitian dan pembahasan dapat diambil beberapa kesimpulan, antara lain :

1. Ada Pengaruh efektifitas yang signifikan terhadap Kinerja Pegawai Pada Kantor Kecamatan Banggae Timur, secara parsial.

2. Ada Pengaruh Efisiensi Kerja yang signifikan terhadap Kinerja Pegawai Pada Kantor Kecamatan Banggae Timur, secara parsial.

3. Ada Pengaruh yang signifikan antara Efektifitas dan Efisiensi Kerja terhadap Kinerja Pegawai Pada Kantor Kecamatan Banggae Timur secara simultan dan dari hasil tersebut menunjukkan bahwa nilai kedua variabel tersebut berpengaruh terhadap pencapaian Kinerja Pegawai yang optimal.

\subsection{Saran}

Berdasarkan hasil penelitian dan analisa hasil penelitian, ada beberapa saran yang dapat penulis berikan, antara lain :
1. Ketetapan waktu dalam menyelasaikan suatu pekerjaan merupakan faktor utama. semakin lama tugas dibebankan itu dikerjakan, maka semakin banyak tugas lain yang menyusul dan hal ini memperkecil tingkat efektifitas kerja karena memakan waktu yang tidak sedikit. Maka diperlukan adanya penegakan disiplin yang lebih ketat terhadap pegawai yang melakukan tindakan indisipliner, dimana tidak hanya sebatas pemberian teguran saja tetapi perlu pemberian sanksi adminisitratif sesuai aturan yang berlaku

2. Efisiensi kerja sering dilakukan pada berbagai bidang kehidupan manusia yang tentunya memiliki tujuan sebagai alasan dilakukanya efisiensi kerja, secara umum tujuan efisiensi kerja adalah Untuk mencapai suatu hasil atau tujuan sesuai dengan yang di harapkan. Nah untuk itu pembinaan dan pengawasan harus terus menerus dilakukan untuk menjaga agar setiap pegawai dapat melaksakan tugastugasnya dengan baik.

3. Untuk meningkatkan kinerja pegawai dapat dilakukan dengan cara memberikan motivasi bagi pegawai agar semangat dalam bekerja sehingga meningkatkan efektifitas dan efisiensi kerja.

\section{DAFTAR PUSTAKA}

A Anwar Prabu mangku negara (2011:69), Manajemen sumber daya Manusia Perusahaan. Bandung : PT Remaja Rosdakarya.

Dessler, (2008:41), Manajemen Sumber Daya Manusia, Jakarta : Indeks.

Daft (2019 :12), Manajemen (Fifth Edition) Nasville : Tennessee. 
Edmondson (2007: Dalam Tarigan, dkk, 2012:28) Suatu Kinerja Tim

Gie $\quad(2010 \quad$ :173), Administrasi Perkantoran Modern, Liberty, Yogyakarta

Gie (2012:27), Kamus Administrasi. Jakarta : Edisi Kedua, Gunung Agung

Huetal, 2009 Team work kesatuan nilai, kesuksesan anggota Tim.

IIyas, 2011. Kinerja, Teori, Penilaian dan Pelatihan. Jakarta. BP FKUM UI.

Nelson Tonks, (2007: Dalam Tarigan dkk: 2012:25) Komunikasi yang di bangun dengan baik.

Nasution, (2010 : 230) Manajemen Mutu Terpadu. Bogor. Ghalia

Poernomo, (2019 : 104) Kerja Sama Sekelompok

Prawirasentono, (2010 : 170) Kebijakan Kinerja Karyawan. Yogyakarta : BPFE, 1999

Prasetyo Budi Saksono,( 2009) . Dalam Menuju SDM. Budi Aksara. Jakarta :

Rivai (2009 : 15-17) Manajemen Sumber Daya Manusia, Jakarta Cetakan Kesembilan

Rivai, (2010 :15) Manajemen Sumber Daya Manusia Untuk perusahaan dari Teori ke Praktik. Jakarta : PT Raja Grefindo.

Soedarmanto (2015) Kinerja dan Pengembngan Kompetensi SDM Yogyakarta : Pustaka Belajar 